\title{
Pengaruh gaya kepemimpinan dan stress kerja terhadap kinerja karyawan RSU. Queen Latifa Yogyakarta
}

\author{
${ }^{1 *}$ Tien Suhartini, ${ }^{2}$ Rifqi Andika Ramadhan \\ 1,2 Universitas Alma Ata. Jl. Brawijaya No.99, Tamantirto, Daerah Istimewa Yogyakarta \\ *e-mail korespondensi: tienummufarah10@gmail.com
}

\begin{tabular}{l|l}
\hline \hline \multicolumn{1}{c}{ Article Info } & \multicolumn{1}{c}{ Abstract } \\
\hline \hline Keywords: & The purpose of this study was to empirically examine the effect of leadership style \\
leadership style, & and work stress on employee performance at Queen Latifa General Hospital \\
work stress, & Yogyakarta. This type of research is quantitative research with causal associative \\
employee & design. The population of this study were permanent and contract employees at the \\
performance, & front office of Queen Latifa General Hospital Yogyakarta. The number of samples \\
hospital & in this study were 35 respondents. The data analysis method used is Multiple \\
& Regression Analysis, T Test (Partial), F Test (Simultaneous Significance Test), \\
& Coefficient of Determination Test (R2). The results of this study indicate that \\
& leadership style has a positive and significant effect on employee performance, while \\
& job stress has no effect on employee performance. The results of the F test obtained \\
& a calculated F value of 4.609 with a sig value of 0.017, which means that the \\
& independent variables have a simultaneous effect, although not significant. $R$ Square \\
& value of 0.224 which means that employee performance is influenced by leadership \\
& style and work stress by 22.4\%, while the remaining $77.6 \%$ is explained by other \\
& variables not examined in this study.
\end{tabular}

Info Artikel

Abstrak

\begin{abstract}
Kata Kunci: gaya
kepemimpinan, stress kerja, kinerja karyawan, rumah sakit

Tujuan penelitian ini adalah untuk menguji secara empiris pengaruh gaya kepemimpinan dan stres kerja terhadap kinerja karyawan di Rumah Sakit Umum Queen Latifa Yogyakarta. Jenis penelitian ini adalah penelitian kuantitatif dengan desain kausal asosiatif. Populasi penelitian ini adalah karyawan tetap dan kontrak di front office Rumah Sakit Umum Queen Latifa Yogyakarta. Jumlah sampel dalam penelitian ini adalah 35 responden. Metode analisis data yang digunakan adalah Analisis Regresi Berganda, Uji T (Parsial), Uji F (Uji Signifikansi Simultan), Uji Koefisien Determinasi (R2). Hasil penelitian ini menunjukkan bahwa gaya kepemimpinan berpengaruh positif dan signifikan terhadap kinerja karyawan, sedangkan stres kerja tidak berpengaruh terhadap kinerja karyawan. Hasil uji $\mathrm{F}$ diperoleh nilai $\mathrm{F}$ hitung sebesar 4,609 dengan nilai sig sebesar 0,017 yang berarti variabel bebas berpengaruh secara simultan walaupun tidak signifikan. Nilai $R$ Square sebesar 0,224 yang artinya kinerja karyawan dipengaruhi oleh gaya kepemimpinan dan stres kerja sebesar $22,4 \%$, sedangkan sisanya sebesar $77,6 \%$ dijelaskan oleh variabel lain yang tidak diteliti dalam penelitian ini.
\end{abstract}




\section{PENDAHULUAN}

Kepemimpinan di Indonesia menjadi sebuah masalah klasik dan menarik serta berpengaruh besar dalam kehidupan organisasi. Gagal atau berhasilnya suatu perusahaan ditentukan oleh kepemimpinan. Pemimpin dituntut untuk bertanggung jawab ketika terjadi kegagalan dalam suatu pekerjaan, hal ini memposisikan pemimpin pada bagian terpenting dalam suatu organisasi. Pemimpin bertindak untuk menghasilkan pola konsisten dalam sebuah keputusan, sehingga dapat ditemukan solusi atas suatu permasalahan (Thoha \& Avandana, 2020).

Seorang pemimpin dituntut peka atas perubahan sekitar lingkungan kerja, serta mampu menganalisa strength and weakness atas sumber daya manusianya sehingga mampu memperoleh hasil positif dari kinerja karyawan untuk kepentingan organisasi. Pemimpin dikatakan efektif apabila dapat mempengaruhi para pengikutnya untuk berjiwa optimisme, rasa percaya diri serta memiliki komitmen kepada tujuan dan misi organisasi (Puccio et al., 2020).

Rehman et al. (2020) menyampaikan bahwa diperlukan seorang manajer yang mampu mengelola karyawan secara efektif, memiliki keterampilan manajemen, dan kepemimpinan. Manajer juga diharuskan mampu memahami serta menyadari apa yang menjadi tantangan terpenting yang dia hadapi dengan cara yang seperti apa untuk menerapkan seluruh aspek dimaksud agar tepat dalam situasi dan kondisi tertentu untuk memperoleh hasil optimum berupa SDM yang bermutu. Oleh karena itu, gaya seseorang dalam memimpin pun menjadi faktor penentu bagi peningkatan maupun penurunan kinerja karyawan selain dari berapa tingginya tingkat stres kerja yang dialami oleh karyawan.

Konsep kinerja adalah acuan perilaku seseorang dalam menetapkan pencapaian target dan sasaran kerja, serta cara bekerja dan sikap pribadi seseorang. Tercapainya tujuan organisasi karena upaya para pelaku yang ada dalam organisasi memiliki kinerja baik. Seorang karyawan dengan loyalitas kinerja yang tinggi dapat mencapai tujuan dan sasaran perusahaan.

\section{KAJIAN TEORI DAN HIPOTESIS}

Amirullah (2015) menyampaikan bahwa pemimpin adalah orang yang memiliki kemampuan mempengaruhi orang lain dan berwenang dalam memberi tugas sesuai tujuan yang ditentukan dengan pola hubungan yang baik. Trisnawati dan Saefullah (2015) menyatakan bahwa kepemimpinan adalah seseorang yang diterima oleh orang yang dipimpin karena layak sebagai sosok atasan mereka dengan kemampuan mempengaruhi perilaku orang lain tanpa menggunakan kekuatan. Oleh karenanya kepemimpinan diartikan sebagai tahapan proses dalam mempengaruhi serta mengarahkan para karyawannya dalam mengerjakan tugas / pekerjaan yang diberikan kepada mereka, dan hal ini berpotensi untuk membuat orang yang dipimpin mengikuti apa yang dikehendaki pimpinannya menjadi terealisasi. Nurlia (2017) menyampaikan bahwa gaya kepemimpinan adalah sekumpulan ciri-ciri yang digunakan dalam mempengaruhi para bawahan untuk mencapai sasarannya. 
Atau dapat diartikan pula bahwa gaya kepemimpinan merupakan strategi yang diterapkan seorang pemimpin dalam membuat pola perilaku.

Stres kerja merupakan suatu kondisi yang mempengaruhi proses berfikir, emosi bahkan kondisi seseorang yang menyebabkan ketegangan. Alhasil, stres tinggi yang dialami karyawan tidak terkendali sehingga berdampak pada kemampuan kerja karyawan dalam menghadapi tugas-tugasnya dan menurunkan kinerjanya (Handoko, 2011). Semua respon yang ditunjukkan kepada stresor baik respon fisiologi atau psikologi disebut stres. Keterkaitan stres kerja dengan kinerja pegawai berhubungan erat, hal ini sebagaimana yang dikemukakan oleh Handoko (2011), bahwa stres kerja yang dialami oleh pegawai bisa saja menjadi faktor positif dalam membantu meningkatkan kinerja, bahkan sebaliknya bisa menjadi faktor negatif yaitu menghambat atau merusak kinerja pegawai. Organisasi yang memiliki kinerja individu yang baik cenderung memiliki kontribusi yang baik pula untuk organisasinya. Penelitian-penelitian sebelumnya tentang stres kerja dan kinerja karyawan telah dilakukan, antara lain yang dilakukan Agow et al. (2020) menyatakan bahwa variabel stres kerja berpengaruh negatif terhadap kinerja karyawan. Penelitian yang dilakukan Iswari dan Pradhanawati (2018) menunjukkan bahwa terdapat korelasi kuat antara variabel peran ganda, stres kerja, dan motivasi kerja terhadap kinerja karyawan. Penelitian yang dilaksanakan oleh Sugiarti (2018) menunjukkan adanya pengaruh yang positif dan signifikan antara stres kerja terhadap kinerja karyawan.

Menurut Kasmir (2016), peninjauan kinerja dilakukan secara periodik dalam meninjau serta mengevaluasi hasil kinerja individu. Sementara itu, menurut Fahmi (2016), kinerja bersifat profit oriented dan non profit oriented yang diperoleh dari suatu organisasi tersebut selama satu periode waktu. Suatu kondisi yang harus diketahui oleh pihak tertentu dan dikonfimasikan tingkat pencapaian hasil individunya dengan rujukan visi yang diemban organisasi, sekaligus agar dapat diketahui dampak positif dan negatif dari suatu kebijakan operasional (Noor, 2013). Mangkunegara \& Prabu (2013) menyampaikan bahwa kinerja karyawan adalah prestasi kerja atau hasil kerja yang dicapai sumber daya manusia dalam periode tugasnya baik kualitas maupun kuantitas sesuai tanggung jawabnya. Pengertian kinerja menurut Amirullah (2015) adalah fungsi pekerjaan atau aktivitas selama periode khusus atas hasil yang diproduksi.

Berdasarkan uraian-uraian diatas maka hipotesis penelitian ini adalah sebagai berikut:

$\mathrm{H}_{1}$ : Gaya kepemimpinan berpengaruh positif dan signifikan terhadap kinerja karyawan

$\mathrm{H}_{2}$ : Stres kerja berpengaruh positif dan signifikan terhadap kinerja karyawan

$\mathrm{H}_{3}$ : Gaya kepemimpinan dan stres kerja berpengaruh positif dan signifikan terhadap kinerja karyawan

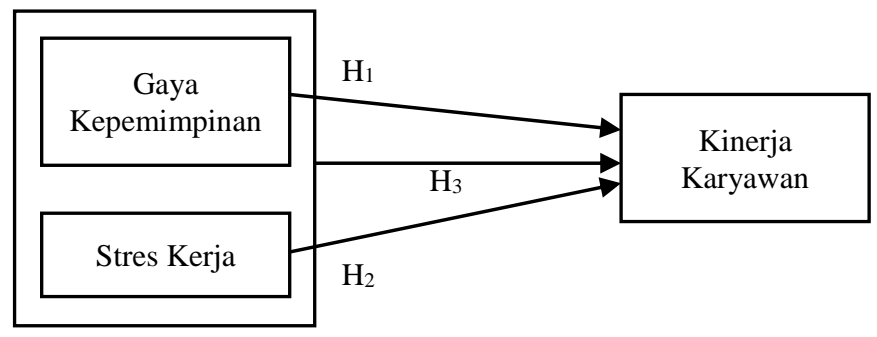

Gambar 1. Model Penelitian 


\section{METODE PENELITIAN}

Penelitian ini merupakan penelitian kuantitatif dengan dua variabel independen dan satu variabel dependen. Penelitian ini akan menggunakan desain penelitian yang bersifat asosiatif kausal yaitu penelitian yang bertujuan untuk mengetahui hubungan atau korelasi atas sebab akibat 2 (dua) variabel atau lebih, dengan variabel bebas atau independent variable terhadap variabel terikat atau dependent variable (Gujarati et al., 2012). Penelitian ini menggunakan variabel terikat berupa Kinerja Karyawan, sedangkan variabel bebasnya berupa Gaya Kepemimpinan dan Stres Kerja.

Populasi dalam penelitian ini adalah karyawan tetap maupun kontrak pada bagian front office yang diantaranya bagian Pendaftaran/Rekam Medik, Poliklinik, IGD, Laboratorium, Radiologi dan Kasir di RSU Queen Latifa Yogyakarta. Sampel dalam penelitian ini ditetapkan sebanyak 35 orang yaitu yang bersedia mengisi kuesioner yang disampaikan secara daring.

Uji yang digunakan dalam penelitian ini adalah validitas dan reliabilitas untuk menguji kuesioner yang digunakan, uji asumsi klasik untuk menilai variabel-variabel independen yang digunakan, dan uji regresi untuk mengetahui pengaruh variabel independen terhadap variabel dependen.

\section{HASIL DAN PEMBAHASAN}

Uji validitas yang dilaksanakan menunjukkan bahwa nilai $r$ hitung disemua item pernyataan lebih besar dari 0,334 yang artinya keseluruhan variabel pernyataannya valid. Uji reliabilitas yang dilaksanakan menunjukkan hasil semua nilai Cronbach's Alpha untuk seluruh variabel lebih besar dari 0,60 yang artinya alat ukur yang digunakan ini reliabel atau dapat dipercaya. Uji normalitas yang dilaksanakan menunjukkan hasil bahwa variabel dependen dan variabel independen memiliki distribusi yang normal, karena data yang telah diolah menyebar dan mengikuti disekitar area garis diagonal, maka disimpulkan data yang telah dilakukan pengujian distribusi normal dan layak digunakan. Uji heteroskedastisitas yang dilaksanakan dengan pengujian scatterplot menunjukkan bahwa plot menyebar tidak mengumpul disatu titik / acak di atas dan di bawah angka 0 pada sumbu Regression Studentized Residual, oleh karenanya metode regresi yang terbentuk tidak terjadi heteroskedastisitas berdasarkan hasil uji metode analisis grafik. Uji multikolinieritas menunjukkan hasil nilai VIF (Variance Inflation Factor) Gaya Kepemimpinan dan Stres Kerja yang masing-masing sebesar 1,038 artinya angka tersebut kurang dari $(<)$ 10. Jadi disimpulkan seluruh variabel independen bebas multikolinieritas. Persamaan regresi dalam penelitian ini adalah sebagai berikut:

$$
\mathrm{Y}=29,452+0,336 \mathrm{X} 1-0,010 \mathrm{X} 2+\varepsilon
$$

Keterangan :

$\mathrm{Y} \quad=$ Kinerja Karyawan $\quad \mathrm{X} 1 \quad$ = Gaya Kepemimpinan

a $=$ Konstanta X2 = Stres Kerja

b1, b2 = Koefisiensi Regresi $\quad \varepsilon=$ Standar error 
Hasil analisis data menunjukkan bahwa gaya kepemimpinan berpengaruh positif dan signifikan terhadap kinerja karyawan RSU Queen Latifa Yogyakarta, dibuktikan dengan nilai t hitung di angka 2,971 lebih besar dari t tabel nya 2,040 dan pengaruhnya signifikan dibuktikan dengan nilai sig nya 0,006 lebih kecil dari tingkat sig yang ditetapkan yaitu 0,05. Hasil penelitian ini sejalan dengan penelitian yang dilakukan oleh Karma, Yasa, dan Ratnadi (2017) yang menyatakan bahwa gaya kepemimpinan berpengaruh signifikan terhadap kinerja karyawan. Hasil penelitian ini senada dengan Maesaroh dan Bella (2019), Brawijaya dan Lantrini (2020), Prawitasari dan Bustari (2020), Nasution (2020), Soelistyoningrum (2020), Purnama et al. (2020), dan Zulfikar (2020).

Stres Kerja tidak memiliki pengaruh terhadap kinerja karyawan RSU Queen Latifa Yogyakarta, dibuktikan dengan nilai t hitung di angka -0,047 lebih kecil dari t tabel 2,040 serta sig $=0,963$ lebih besar dari tingkat signifikansi yang ditetapkan yaitu 0.05. Hal ini terjadi dikarenakan adanya perbedaan pandangan dari setiap responden terkait stres kerja. Sebagian besar karyawan menilai bahwa stres kerja sebagai nilai yang positif dalam peningkatan kinerjanya, dan sebagian lainnya menilai bahwa stres kerja sebagai nilai negatif yang dapat menurunkan kualitas kinerjanya. Hasil penelitian ini sejalan dengan Agustina et al. (2019), Polopadang et al. (2019), Fadhilah (2020), Muhson dan Mahfudiyanto (2020), Cay \& Arbian (2020), dan Muis et al. (2021).

Pengujian F test didapatkan nilai F hitung sebesar 4,609 lebih besar dari F tabel yaitu 3,28 , yang artinya gaya kepemimpinan dan stres kerja secara bersama-sama memiliki pengaruh yang positif terhadap kinerja karyawan, walaupun tidak signifikan dengan angka sig $=0,017$ lebih besar dari tingkat signifikansi yang ditetapkan yaitu 0,05. Hal ini dikarenakan gaya kepemimpinan dan stres kerja sama-sama memiliki pengaruh akan tetapi respon/tanggapan yang diberikan antar satu sama lain berbeda. Hasil penelitian ini sejalan dengan penelitian Diansyah (2016) yang menyatakan bahwa variabel gaya kepemimpinan dan variabel stres kerja secara simultan berpengaruh positif. Koefisien determinasi ( $R$ square) adalah sebesar 0,224 yang berarti kedua variabel bebas gaya kepemimpinan dan stres kerja berpengaruh terhadap variabel terikat yaitu kinerja karyawan RSU Queen Latifa Yogyakarta sebesar 22,4\%, sedangkan sisanya 77,6\% dipengaruhi oleh variabel lain yang tidak termasuk dalam penelitian ini.

\section{KESIMPULAN DAN SARAN}

Analisis data yang dilaksanakan menunjukkan hasil bahwa gaya kepemimpinan berpengaruh positif dan signifikan terhadap kinerja karyawan RSU Queen Latifa Yogyakarta, stres kerja tidak memiliki pengaruh terhadap kinerja karyawan RSU Queen Latifa Yogyakarta, gaya kepemimpinan dan stres kerja secara bersama-sama berpengaruh positif terhadap kinerja karyawan RSU Queen Latifa Yogyakarta. Saran untuk penelitian selanjutnya adalah meneliti faktor lain yang mempengaruhi kinerja, misalnya kompensasi berupa gaji dan tunjangan. 


\section{DAFTAR PUSTAKA}

Agow, F.M., Adolfina, \& Dotulong, L.O.H. (2020). Pengaruh Kualitas Kehidupan Kerja, Komunikasi Organisasi Dan Kepuasan Kerja Terhadap Kinerja Karyawan Pada Pt. Pln Ulp Airmadidi. Jurnal Emba: Jurnal Riset Ekonomi, Manajemen, Bisnis Dan Akuntansi, 8(1), 116-125.

Agustina, R., \& Rastika, E. (2019). Pengaruh Stres Kerja, Motivasi Dan Kompensasi Terhadap Kinerja Karyawan PT Telkom Akses Sentral Telepon Otomat (STO) 1 Centrum Cabang Banjarmasin. Dinamika Ekonomi-Jurnal Ekonomi dan Bisnis, 12(1), 102-116.

Amirullah, (2015). Pengantar Manajemen. Jakarta. Penerbit: Mitra Wacana Media.

Brawijaya, I. G. A., dan Lantrini, M. Y., (2020), Efektivitas SIPKD, Gaya Kepemimpinan, dan Lingkungan Kerja Pada Kinerja Karyawan Dinas Pariwisata Provinsi Bali, E-Jurnal Akuntansi, 30(2), 517-527.

Cay, S., dan Arbian, O. S., (2020), Pengaruh Stres Kerja dan Rotasi Kerja terhadap Kinerja Karyawan pada PT Astra Credit Companies Cabang Pondok Cabe Tangerang Selatan, Jurnal Semarak, 3(1), 85-95.

Diansyah, R. N., (2016). Pengaruh gaya kepemimpinan dan stress kerja terhadap kinerja pegawai (Studi kasus Dinas Kesehatan Kabupaten Jember), Bisma: Jurnal Bisnis dan Manajemen, 10(3), 307-318.

Fadhilah, U., (2020), Pengaruh Work Family Conflict dan Stres Kerja terhadap Kinerja Karyawan PT BPR Syariah Lantabur Tebuireng Jombang, BIMA: Journal of Business and Innovation Management, 2(3), 351-369.

Fahmi, I, (2016). Pengantar Manajemen Sumber Daya Manusia Konsep dan Kinerja. Jakarta: Mitra Wacana Media.

Gujarati, D. N., Porter, D. C., \& Gunasekar, S. (2012). Basic econometrics. Tata McGrawHill Education.

Handoko, (2011). Dasar-dasar Stres Kerja. Penerbit Liberty, Yogyakarta.

Iswari, R. I., dan Pradhanawati, A., (2018), Pengaruh Peran Ganda, Stres Kerja, dan Motivasi Kerja terhadap Kinerja Karyawan Perempuan, Jurnal Administrasi Bisnis, 7(2), 83-94.

Karma, K. F. A., Yasa, G. W., \& Ratnadi, N. M. D., (2017). Pengaruh gaya kepemimpinan situasional, budaya organisasi dan motivasi pada kinerja karyawan di PT Bank Pembangunan Daerah Bali Cabang Badung, E-Jurnal Akuntansi Universitas Udayana, 19(2), 3823-3856.

Kasmir. (2016). Manajemen Sumber Daya Manusia Teori dan Praktik. Jakarta: Rajagrafindo Persada.

Maesaroh dan Bella, S., (2019), Pengaruh Gaya Kepemimpinan dan Motivasi Kerja terhadap Kinerja Karyawan di PT Kulit Murni Asia Tenggara, The Asia Pacific Journal of Management Studies, 6(3), 145-156.

Mangkunegara, A.P. (2013). Evaluasi Kinerja SDM. Bandung. Penerbit: PT. Refika Aditama.

Mangkunegara, A. P., \& Prabu, A. (2013). Manajemen Sumber Daya Manusia Perusahaan. PT. Remaja Rosda Karya Bandung. Jawa Barat: Bintang mandiri Finance.

Muhson, A. H., dan Mahfudiyanto, (2020), Pengaruh Kepuasan Kerja dan Stres Kerja terhadap Kinerja Karyawan (Studi Kasus pada Bagian Pelinting di KSU Perdula Ngoro Jombang), BIMA: Journal of Business and Innovation Management, 2(3), 325-337. 
Muis, M., Nai'em, M. F., Arsin, A. A., Darwis, A. M., Thamrin, Y., dan Hans, N. A. P., (2021), The effect of multiple role conflicts and work stress on the work performance of female employees, Gaceta Sanitaria, 35(51), 590-593.

Nasution, L., (2020), Pengaruh Gaya Kepemimpinan terhadap Kinerja Karyawan pada Dinas Perhubungan Provinsi Sumatera Utara, Jurnal Ilmiah Metadata, 2(2), 120-127.

Noor, Juliansyah. (2013). Penelitian Ilmu Manajamen. Jakarta: Prenadamedia Group.

Nurlia, R. (2017). Pengaruh Gaya Kepemimpinan terhadap Kinerja Karyawan pada PT. AlIjarah Indonesia Finance Lampung. Skripsi. UIN Raden Intan Lampung.

Polopadang, K. Y., Tewal, B., dan Walangitan, M. D., (2019), Dampak Konflik dan Stres Kerja terhadap Kepuasan Kerja dan Kinerja Karyawan PT Tirta Investama (Danone) Aqua Airmadidi, Jurnal EMBA: Jurnal Riset Ekonomi, Manajemen, Bisnis, dan Akuntansi, 7(4), 5215-5224.

Prawitasari, A., dan Bustari, D., (2020), Hubungan antara Gaya Kepemimpinan, Semangat kerja, dan Pengembangan Karir dengan Kinerja Karyawan di PT Agung Automall Cabang Bengkulu, Creative Research Management Journal, 3(1), 29-40.

Puccio, G. J., Burnett, C., Acar, S., Yudess, J. A., Holinger, M., \& Cabra, J. F. (2020). Creative problem solving in small groups: the effects of creativity training on idea generation, solution creativity, and leadership effectiveness. The Journal of Creative Behavior, 54(2), 453-471.

Purnama, D. T., Arisandi, W., dan Remiasa, M., (2020), Pengaruh Gaya Kepemimpinan terhadap Kinerja Karyawan di Hotel Puri Gendis Trawas, Jurnal Hospitality dan Manajemen Jasa, 8(1), 107-119.

Rehman, S. U., Shahzad, M., Farooq, M. S., \& Javaid, M. U. (2020). Impact of leadership behavior of a project manager on his/her subordinate's job-attitudes and joboutcomes. Asia Pacific Management Review, 25(1), 38-47.

Soelistyoningrum, J. N., (2020), Pengaruh Gender dan Gaya Kepemimpinan terhadap Kinerja Karyawan (Studi Kasus PT XYZ), ESENSI: Jurnal Manajemen dan Bisnis, 23(1), 85-91.

Sugiarti, E., (2018), Pengaruh Stres Kerja terhadap Kinerja Karyawan pada PT PLN (Persero) Area Bintaro Tangsel, Jurnal Semarak, 1(2).

Thoha, N., \& Avandana, I. M. N. W. (2020). Project Managers' Leadership Styles and Their Effects on Project Management Performance. Pertanika Journal of Social Sciences \& Humanities, 28(2), 803-816.

Trisnawati, E. dan Saefullah, K. (2015). Pengantar Manajemen, Jakarta, Penerbit: Prenadamedia Group.

Zulfikar, M. D. (2020), Pengaruh Gaya Kepemimpinan dan Analisis Jabatan terhadap Kinerja Karyawan pada Universitas Jabal Ghafur Sigli, Jurnal Real Riset, 2(3), 113-125. 